\title{
An analysis of the latest trends of the complex development of the Croatian-Hungarian border area
}

\author{
TvrTKo JosIP ČELAN ${ }^{1}$
}

\begin{abstract}
This paper analyses the geographical feature of the Croatian-Hungarian cross-border area, focusing on recent changes and socio-economic trends of the last decade. In the paper current demographic, cross-border traffic and mobility trends are examined. Special attention is devoted to the spatial structure of the area and its key demographic indicators, modified during the last intercensal period between 2001 and 2011. Demographic data are analysed on the level of NUTS III units, as they provide the statistical basis for planning and they are designated as co-operation units in the joint bilateral cross-border operational programme financed by the EU. The transition that has taken place in the last years is observed in relation to the Croatian accession to the $\mathrm{EU}$ and to the full membership achieved in 2013. The Croatian-Hungarian cross-border co-operation has been intensified since 2007. More EU funds became available than before, which brought about the possibility for stronger cohesion in the area and, accordingly, it has triggered territorial transformations. The main goal of this research is to define whether changes having taken place in the border region since 2007 created a genuine transborder region. The assumption is that current development trends, although the most intensive in the last 100 years, are still not sufficient enough to mitigate the huge geographical handicap, the transport and language barriers and in general the strong periphery status of the border area in comparison to the capital cities Zagreb and Budapest.
\end{abstract}

Keywords: peripherality, geographical handicap, regional policy, transport geography, EU cohesion policy, cross-border co-operation Croatian-Hungarian border area.

\section{Introduction}

The term "border" often has a negative connotation for being a separating line, a warning signal not to cross a line between the allowed and the forbidden (СтокєоsА, K. et al. 2014). The awareness of both mental and factual borders in our life has made them a research topic in almost all disciplines - including geography. Since the end of the 1980s the status of state borders has become a rather popular topic in European geography and border areas have been continuously analysed and discussed. Cross-border co-operation is one of the most popular subjects in the border research (van Houtum, $\mathrm{H}$. 2000). Despite the wide scientific interest in the problems of state borders the CroatianHungarian border area has not attracted special attention in the literature during the last 20 years. In Croatia it has almost exclusively been published by the researchers at the Department of Geography of the Faculty of Science of the University of Zagreb (ČELAN, T.J. 2014). In Hungary, the Hungarian-Croatian border and its related developments have gained wider attention and have been in the focus of research at the Centre for Economic and Regional Studies of Hungarian Academy of Sciences in Pécs and the Institute of Geography at the University of Pécs as well.

The question of state borders (separating vs. integrating) have been in the centre of academic attention in Central Europe due

\footnotetext{
${ }^{1} \mathrm{PhD}$-student, University of Pécs, Doctoral School of Earth Sciences; presently employed at the Joint Secretariat of the Interreg V-A Hungary-Croatia Co-operation Programme. Address: H-9707 Szombathely, Szabó Imre u. 31. E-mail: tvrtko_josip_celan@yahoo.com
} 
to historical traditions, and it has further strengthened with the boom of EU integration in the period between 1995 and 2007. After the fall of the communist regimes, the countries of the region joined to the EU one by one, and, as a result, cross-border relations have increased both in numbers and in intensity (Gulyás, L. et al. 2013). Due to the intensification of the co-operation between former communist countries and well-developed EU states, border areas became important fields of economic development, with a role to connect the neighbouring areas and even to form transborder regions (OpAčić, V.T. et al. 2004).

According to Buffon (1993) and Opačić (2004) transborder region can be defined as a special form of peripheral region, socially and economically affected by the border and characterised by a significant level of transborder connections and integration (BUFFON, M. 1993; Opačić, V.T. 2004). According to MarTinez (1994) transborder region is a functional region, being the result of a complex development. MARTINEZ also made difference between different types of border areas, like: alienated, co-existing, mutually co-operating and integrated border areas. According to Perkmann (2003), a cross-border region is a territorial unit that comprises contiguous sub-national units from two or more nation states. Cross-border regions differ from basic ceremonial contacts to long-lasting and effective co-operations, attached or integrated into the multilevel policy implementation networks constituted by EU regional policy. In this paper we would like to examine whether the Croatian-Hungarian border area has attained the status of transborder region, or still exists just as a cross-border area.

The demographical conditions and the spatial structure of the Croatian-Hungarian border was analysed in the latest planning process $^{2}$ and significantly more weaknesses were pointed out than strengths. They included: a decreasing population, negative

\footnotetext{
${ }^{2}$ Situation and SWOT Analysis: Interreg V-A HungaryCroatia Co-operation Programme 2014-2020: http:// www.huhr-cbc.com/en/official-documents.
}

balance of migration, ageing (see: Planning documents of the Interreg V-A HungaryCroatia Co-operation Programme 20142020). Negative demographic trends increase towards the borderline on the both sides of the national frontier. This reflects that in case of the Croatian-Hungarian border the border position is not an advantage but rather a handicap (OpAčić, V.T. et al. 2004). The size and the structure of settlements, which generally have a rural character, the dominance of small villages and the lack of larger centres directly influence depopulation. The primacy of both capitals (Budapest and Zagreb) has also negatively contributed to the development of other regions, including border areas. The economic position of Budapest has become clearly stronger in the last two decades and its economic primacy increased (PIRISI, G. et al. 2012).

The Hungary-Croatia Cross-border Cooperation Programme 2007-2013 (hereinafter HU-HR (IPA) CBC Programme) as an instrument for minimising the existing border handicap has been one of the possible financial sources for overcoming problems in the area, from demographic issues to cross-border traffic and mobility. In the period 2007-2013. The instrument for pre-accession assistance (IPA) brought significant changes to Hungarian-Croatian cross-border co-operation. The question is whether the established bilateral programme and the 169 joint projects brought about a balanced development, or it could be considered artificial to a certain extent.

\section{Geographical characteristics of the Croatian-Hungarian border zone}

The 355-kilometre ${ }^{3}$ stretch of the border between Croatia and Hungary is the most unique and complex section of the Hungarian boundaries, and this is the only one that has a long historical tradition. Despite fre-

\footnotetext{
${ }^{3}$ The same figure is also indicated by State Geodetic Administration, Zagreb, Croatia. CIA (The World Factbook) gives different data on the border length (Figure 1).
} 
quent disputes the border retained its peaceful character (Hajdú, Z. 2004). The CroatianHungarian boundary, colloquially often identified with the Drava river, as a typical natural boundary, has been on its major parts one of the oldest European borders. Still, it is a complex border with diverse origins and significant deviations from the present Drava river bed, as the consequence of its frequent changes in the past (KLEMENČić, M. 1991). Typical lowland river meanders altered the river bed. Rivers Mura and Drava are among the last remaining wetland habitats in Central Europe (UNESCO trans-boundary biosphere reserve from 2012). Several border sections such as Međimurje, Baranja and Prekodravlje ${ }^{4}$ (Crkvenčić, J. and Crkvenčić, M. 2003) have different historical background.

The unique shape of the Croatia has a clear impact on the length of its state borders. Although Hungary comprises significantly larger area than Croatia, the longest Croatian land border with Bosnia and Herzegovina ( $47 \%$ of all Croatian land borders) is even 256 $\mathrm{km}$ longer than the longest Hungarian bor$\operatorname{der}^{5}$ (Figure 1). Except for the Hungarian, all other Croatian land borders derive from the former internal SFRY (Socialist Federative Republic of Yugoslavia) borders, resulting in disputes among the new states and all remained partly unsolved. During the SFRY they were only borders of the federal units and were not confined properly like the Yugoslav border with Hungary. Their recognition as state borders was based on the conclusions of November 1991 formulated by the Badinter Arbitration Committee (ČELAN, T.J. 2014).

Long parts of the boundaries with Bosnia and Herzegovina, Slovenia and Serbia are passing alongside various river beds, but nowhere present an obstacle at such extent as

\footnotetext{
${ }^{4}$ In Hungarian the names are Muraköz, Baranya and "Répás-kerület" (according to Hajdú, Z. 2006).

${ }^{5}$ Data have been compared based on the same source, not to have discrepancies as of the different methodology. Source: CIA-The World Factbook, https://www.cia.gov/library/publications/theworld-factbook.
}

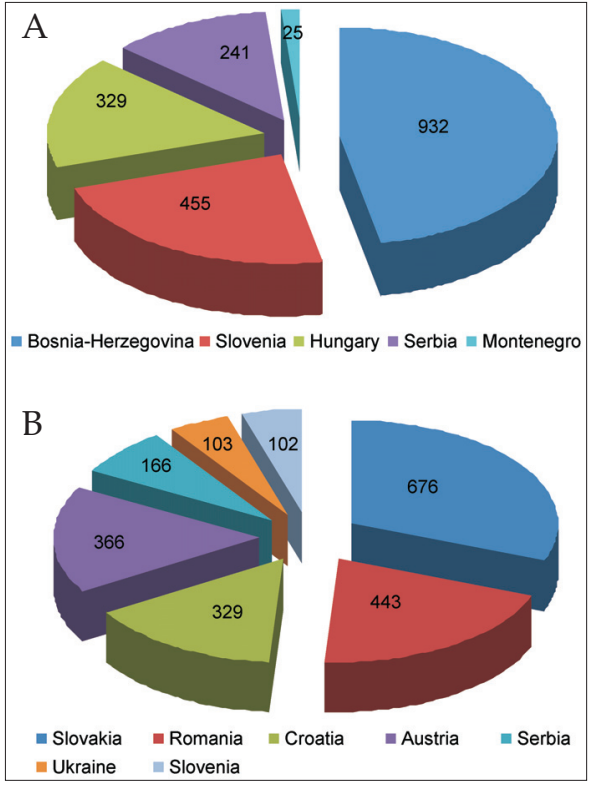

Fig. 1. State land borders of the Republic of Croatia (A) and Hungary (B) per neighbouring countries (in km) Source: CIA-The World Factbook: total land borders of the Republic of Croatia and Hungary.

in the case with Hungary. As of Croatia, its border with Hungary (Figure 1, A) is the $3^{\text {rd }}$ longest (16\%) and as of Hungary (Figure 1, B), its border with Croatia is the $4^{\text {th }}$ longest with the share of 15 percent (https://www.cia.gov/ library/publications/the-world-factbook).

Geographical and transport barriers of Hungary are the strongest with Croatia, having only four cross-border river bridges. Border areas with different geographical endowments have various chances for creating integrated cross-border regions (HARDI, T. 2010). Out of the $355.2 \mathrm{~km}$ of the CroatianHungarian state border the major part in the length of 226.4 kilometres (64\%) goes alongside the river beds of Drava $(180 \mathrm{~km})$ and Mura $(44.6 \mathrm{~km})$. A short $1.8 \mathrm{~km}$ strip passes across the small river Krka (in Hungarian: Kerka) close to the village Alsószemenye ${ }^{6}$.

\footnotetext{
${ }^{6}$ Source: Državna geodetska uprava/ State Geodetic Administration, Zagreb, Croatia: http://www.dgu. $\mathrm{hr}$ official answer of 25.2.2014 on inquiry (Class: 015-02/14-01/03, Number: 541-02-3/1-14-2).
} 


\section{Changes and trends in the development of the Croatian-Hungarian border area}

In this section we examine the development of the Croatian-Hungarian border zone in the light of several aspects, like language barrier, spatial structure and current socio-economic trends, transport, mobility, and EU funded cross-border co-operation.

\section{The Croatian-Hungarian border area as a language barrier}

Although Croatia formed different types of state union with the Kingdom of Hungary from 1102 until 1918, neither the Hungarian language in Croatia nor the Croatian language in Hungary was significantly widespread. Their usage is limited only to the relatively small communities of national minorities. The share of these minorities in the population of Hungary and Croatia is quite low, at 0.3 percent. The number of native speakers is even lower than the representation $^{7}$ of national minorities in both Hungary and Croatia. With the abolition of the official use of Latin (as the lingua franca) in the $19^{\text {th }}$ century, Croatians and Hungarians could no longer understand each other because both nations were very keen and persistent on using their own national languages and none of them deemed it necessary to learn the language of its neighbour (HeKA, L. 2007).

Croatian and Hungarian languages belong to very different families (Indo-European and Uralic/Finno-Ugric) and the language barrier is particularly strong. All these factors led to the fact that bilingualism is not a typical feature of the cross-border area. The number of bilingual population, especially on the Croatian side is negligible. Without English or German proper communication is almost impossible nowadays. The only area where bilingualism is partly identifiable is the border zone of Baranya County (HU) and Osječko-baranjska County (HR), with two

\footnotetext{
${ }^{7}$ Sources: www.dzs.hr and www.ksh.hu (Censuses 2011 and 2001).
}

major cities of Pécs and Osijek. The largest group of Croatian or Hungarian minorities live there and that is the only location where geographical handicap does not exist. Pécs and Osijek are the two major regional centres where it is possible to study Croatian and Hungarian as foreign languages on university level ${ }^{8}$. Comparing the censuses in 2001 and 2011, there is a slight decrease of Hungarian minority in Croatia (16,595 vs. 14,048) whilst in Hungary the number of Croatians $(25,730$ vs. 26,774$)$ has statistically ${ }^{9}$ increased.

The spatial structure and the current socioeconomic trends in the Croatian-Hungarian border area

The development of the spatial polarisation (inland vs. borderland) of an integrated state formation is mostly dependent on the character of a borderline (open or closed) and it is not only conditioned by economic aspects. Actual peripherality has a long and complicated history (HavlíčEK, T. 2007; LANG, T. 2015. Prior to the change of regime, the development of cross-border tourism was hindered by administrative obstacles which made settlements in border regions peripheral. Negative effects also emerged at the border section with Croatia (DÁvid, L. et al. 2011). During the second half of the $20^{\text {th }}$ century the border was a strict and clear dividing line, supported with the development of the Southern Defence System. This background negatively influenced the development of the border area (ČELAN, T.J. 2014).

Between the last two censuses (2001-2011) the total decrease of the population in the border area was $102,864(55,332$ on the

\footnotetext{
${ }^{8}$ In both towns there are also Croatian and Hungarian Education Centres (with kindergarten, primary and grammar school). Several pre-school programmes and primary schools in Hungary can offer minority language or bilingual trainings, http://www hrvatiizvanrh.hr/hr/hmiu/hrvatska-manjina-urepublici-madjarskoj/9 but on university level only Pécs and Osijek offer teaching of Croatian and Hungarian as foreign languages.

9 Sources: www.dzs.hr and www.ksh.hu (Censuses 2011 and 2001).
} 
Hungarian and 47,532 on the Croatian side). Counties (i.e. NUTS III areas) are different ${ }^{10}$ in their size, but they can indicate the demographic trends. Both sides of the border zone have higher population decrease (in percent) than the national averages. Three Hungarian border counties (Zala, Somogy, Baranya), have similar relative decrease of the population (average $5.32 \%$ ). The average decrease is a bit higher $(7.13 \%)$ in the four Croatian counties, but it significantly varies, from 3.91 percent in Međimurska to 10 percent in Virovitičko-podravska. In the previous intercensal period between 1991 and 2001 population decrease showed a total of 82,730; significantly higher in the Croatian part $(54,313)$ than in the Hungarian $(28,417)$. The relative fall of population $(2.7 \%)$ in Hungarian counties proved ${ }^{11}$ to be much lower than in the Croatian counties $(7.5 \%)$.

The intensity of depopulation is strongly influenced by the characteristics of the settlement pattern, which is significantly better on the Hungarian side. One of the main reasons for stronger depopulation on the Croatian side $^{12}$ has been the fragmented settlement pattern (Figure 2).

The average size of settlements is approximately twice bigger on the Hungarian side than on the Croatian one, and the difference in the size of settlements varies more in Hungary from very small villages to bigger towns. Depopulation as a consequence of emigration affects small villages more intensely than larger settlements (OpAčić, V.T. et al. 2004). In Hungary, three towns on the border zone have more than 50,000 inhabitants (Pécs, Kaposvár and Zalaegerszeg) while in Croatia only one settlement, Osijek (Figure 2). In both countries the size of towns correlates with the distance from the border.

\footnotetext{
${ }^{10}$ Counties are smaller in Croatia. Croatia has 21 county including Zagreb, Hungary has 20 with Budapest.

11 Sources: www.dzs.hr and www.ksh.hu (Censuses 2011 and 2001).

${ }^{12}$ In Croatia almost always is the case that more settlements form a local government (town/ municipality), in Hungary it is more frequent to have the 1 settlement=1 local self-government principle.
}

The negative population trends in comparison with the countries' statistics became even worse between 2001 and 2011. The aggregated population decrease between 1991 and 2011 officially amounts to 185,594 , which means almost the combined total population of Osijek, Zalaegerszeg and Nagykanizsa was lost in the border area in the last two decades.

Gross domestic product figures are not very promising either. The GDP per capita value of the region is below the EU and national averages. Koprivničko-križevačka is the most developed among the investigated Croatian border counties ${ }^{13}$ with 82.6 percent of the national average (but Medimurska with 81.9 percent and Osječko-baranjska with 80.1 percent are quite close to it). The least developed, and at the same time the most sparsely populated county in the whole CroatianHungarian border zone is Virovitičko-podravska with only 61.3 percent of the Croatian (10,325 EUR) national per capita GDP. On the Hungarian side, GDP per capita is the highest in Zala (79.8\%) compared to the national average $\left(9,925.8\right.$ EUR). It is the $7^{\text {th }}$ most developed Hungarian country, while Baranya $(64.0 \%)$ and Somogy $(63.4 \%)$ are almost at the bottom $\left(15^{\text {th }}\right.$ and $16^{\text {th }}$ place $)$ out of the 19 Hungarian counties ${ }^{14}$. Virovitičko-podravska and Somogy show equally low performance, like in demographic indicators, and the development of the transport network.

\section{Transport in the Croatian-Hungarian border area}

In the last 15 years Croatia and Hungary have developed their own motorway infrastructure, and both countries are good examples for excessive road developments ${ }^{15}$ in

\footnotetext{
${ }^{13}$ Source: First release, Number: 12.1.2. (14 February, 2014) - CROSTAT, www.dzs.hr Gross Domestic Product for Republic of Croatia, NUTS 2 Level and Counties, 2011.

${ }^{14}$ Source: Hungarian Central Statistical Office (data for year 2011) - http://www.ksh.hu/engstadat.

${ }^{15}$ Hungary reached the milestone $(1,000 \mathrm{~km})$ of constructed motorways in 2007, whilst Croatia already in 2005 (http://www.huka.hr/mrezaautocesta; http://www.motorway.hu/)
} 


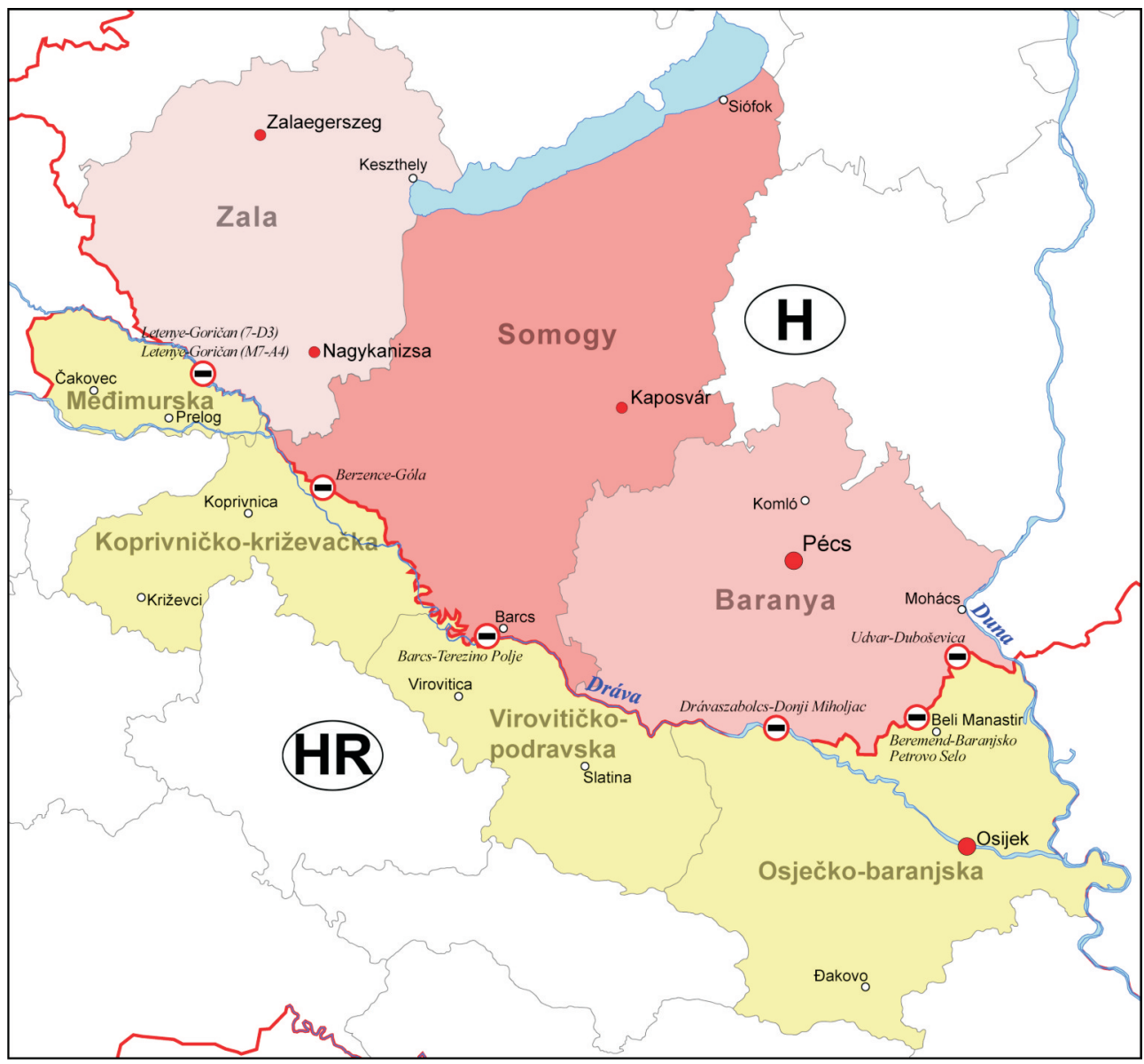

Fig. 2. Map of the border area with the settlements and border crossing points. Source: Own editing in co-operation with Gábor Kovács and János CsApó (University of Pécs).

East Central Europe. The investments were huge, and the maintenance of the network is centralised in both countries managed by large state corporations. The development of the motorway network contributed to the supreme role of the two capital cities linked by the new Zagreb-Budapest axis.

The concentrated traffic channelled to border crossing points resulted in excessive transport shadow areas on both sides of the border. Thus, the peripheral position, especially in the case of the middle section of the border area (Virovitica on the Croatian side and partly Kaposvár on the Hungarian side) has not improved, despite road investments. Proper West-East connections do not exist in Hungary. Only the far West (Čakovec/Nagykanizsa) and the far East (Osijek/Pécs) have really modern road connections (http://www.huka.hr/mrezaautocesta; http://www.motorway.hu/), but only with the capital cities.

Currently, there are only seven road border crossing points along the entire CroatianHungarian frontier. This is not enough for a good level of cross-border transport and accessibility. Three out of the seven border crossings are between Baranja/Baranya, within a very short distance and two of them even 
do not have a river barrier (Figure 2). There are several strong cross-border, mainly cultural contacts and partnerships around Mura and Drava, but the lack of bridges and bordercrossings prevents adequate communication (ČELAN, T.J. 2011, 2013). The only major joint investment in the last decade was one bridge (with names - HR: Most Mura, HU: Zrínyi híd) on the Pan-European transport corridor ${ }^{16}$ $\mathrm{V} / \mathrm{B}$, where the new border crossing Goričan - Letenye II is located. That bridge ${ }^{17}$ connects Zagreb (Zagreb-Goričan motorway A4) and Budapest (Budapest-Letenye motorway M7) from October 2008.

The regulation of the Croatian Government on border crossings published in the Official Gazette No. 79/2013 defines ${ }^{18}$ five more international road border crossings with Hungary (Kotoriba, Donja Dubrava, Legrad, Ferdinandovac, Sopje), but without any concrete plan for construction. Between 2012 and 2015 a project was implemented in Hungary with the task of defining possible new border crossings and the development of crossborder infrastructure with all neighbouring countries, including Croatia. On the Croatian border section 44 possible crossings and construction areas have been analysed. The results of the given project (KÖZOP-3.5.0-09-112012-0003) have just been published and the decision of the Hungarian government was taken in January 2016 on prioritising road and partly bridge construction at four border crossings with Croatia ${ }^{19}$. Future construc-

\footnotetext{
${ }^{16}$ The term Pan-European transport corridor is used, as more appropriate for the region, not EU-TEN $\mathrm{T}$ network. http://ec.europa.eu/transport/themes/ infrastructure/doc/ten-t-country-fiches/ten-tcorridor-map-2013.pdf

${ }^{17}$ Uredba o objavi Ugovora između Vlade Republike Hrvatske i Vlade Republike Mađarske o uspostavi graničnog prijelaza Goričan-Letenye II (...): Official Gazette, Croatia (NN-MU 1 / 2006). http://narodnenovine.nn.hr/medunarodni/default.aspx

${ }^{18}$ Narodne novine- NN 79/2013: Uredba o graničnim prijelazima Republike Hrvatske.

19 1007/2016. (I. 18.) Korm. Határozat: A 2014-2020. évek közötti határ menti közúti infrastruktúrafejlesztésekről. http://www.kozlonyok.hu/nkonline/ MKPDF/hiteles/MK16007.pdf
}

tion depends on the availability of funds and agreements with the Republic of Croatia.

Road traffic from Croatia to Hungary is very limited, comprising only 6.5 percent (in 2012) of the total number of passengers crossing all Croatian state borders. GoričanLetenye is the busiest road border-crossing ${ }^{20}$ along the Croatian-Hungarian section where 60.4 percent of all passengers (Figure 3 ) and 56.8 percent of all vehicles crossed the border in 2004. Figures were similar in 2008 (64\%) and in every other observed year with approximately 60 percent share of passengers. It has to be noted that from 2008 the old and new border crossings of Goričan-Letenye III have been functioning as a joint unit (e.g. trucks can only use the old crossing) ${ }^{21}$ and data used in this paper refer only to one unit. The peak in the number of passengers and vehicles was reached in 2008, while afterwards figures decreased every year until 2013 (Figure 3). As it is primarily a touristic summer border-crossing and used dominantly by cars, it can be easily concluded that the reason for the decline was the financial crisis and the consequent decline of the number of Hungarian tourists ${ }^{22}$ travelling to Croatia (from 453,000 in 2005 to 308,000 in 2013). Since Goričan-Letenye I-II is mainly a summer touristic crossing point, for the analysis of cross-border activity it is important to examine other Croatian-Hungarian border-crossings.

All Croatian-Hungarian border crossings registered decreasing traffic until 2013, with the exception of Duboševica-Udvar, which has been continuously expanding since 2008 (Figure 3), due to the importance of the direction Osijek-Mohács/Pécs-Budapest (PanEuropean corridor V/C). New motorway connections from Zagreb to Osijek (opened in

\footnotetext{
${ }^{20}$ The data are observed for the 6 chosen years in the last 10 years, from 2004 to 2014 . Year 2008 was important due to the opening of the new border crossing Goričan-Letenye, while last three years to indicate recent changes.

${ }^{21}$ The majority (more than $80 \%$ ) of the traffic since 2008 has been channelled through Goričan-Letenye II (new).

${ }^{22}$ Statistical Yearbook of the Republic of Croatia, 2013. http://www.dzs.hr
} 
spring 2009) and from Budapest to Mohács/ Pécs (opened in spring 2010) significantly improved the conditions and shortened the time of travel; however, the connection between Osijek and Mohács is still missing. Based on traffic data (Figure 3) border-crossing points can be categorised in the following way:

- strategic importance: Goričan-Letenye I, II and Duboševica-Udvar,

- medium importance: Terezino Polje-Barcs, Donji Miholjac-Drávaszabolcs,

- minor (local) importance: Gola-Berzence and Baranjsko Petrovo Selo-Beremend.

The total number of passengers in the 2004-2013 decade was the highest $(4,183,381)$ in 2004 with a stagnation; although relatively stable around 4 million, whilst in 2013 a slight increase compared to the previous year was registered for the first time. The latest available data for 2014 show significant increase on all road border-crossings (total number of passengers $4,469,764$ ), as presented by Figure 3. The role of the accession of Croatia to the EU can be measured only in the next years whether the easier crossing of the border with faster police and no customs control, has increased the traffic between the two countries.

As a comparison, in the previous decade (1994-2003), the changes were much more turbulent. From the maximum level of 10.7 million passengers in 1996 to a slight stagnation until 2000, the volume dropped to only 5.1 million by 2003 (OpAčić, V.T. et al. 2004). In 1980 the total number of passengers travelling between the SFRY and Hungary both by road and railway was 7.6 million (PEPEONIK, Z. 1985). The big boom of the cross-border traffic started in the 1990s, after the fall of the „iron curtain“ and had its peak in 1996, right after the end of war (1995) in Croatia. The first reason for the intensified cross-border traffic was a large number of refugees coming to Hungary, escaping from the war. In addition increasing shopping tourism from Croatia to Hungary could be identified driven by the availability of goods and cheaper prices,

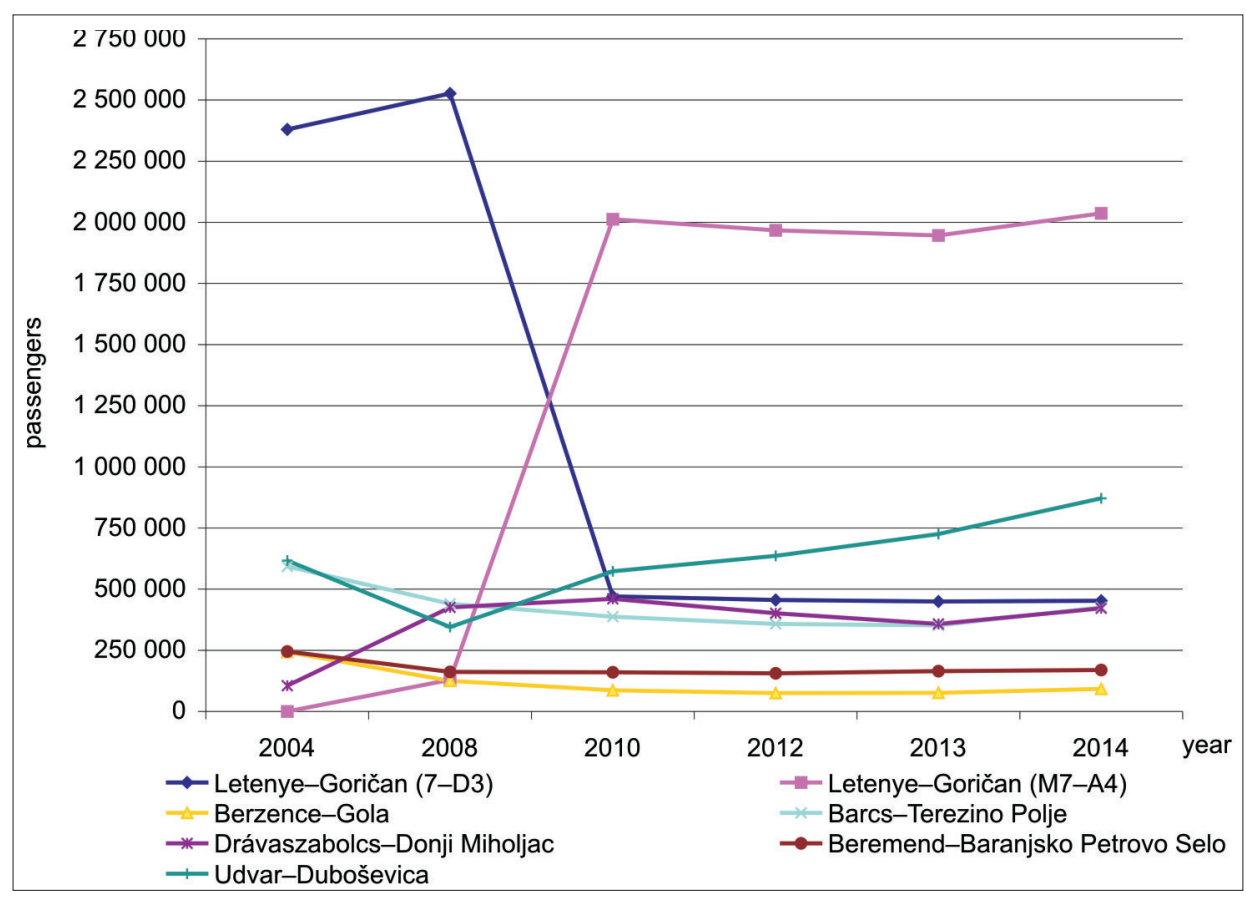

Fig. 3. Border road traffic data of the Croatian-Hungarian border section (2004-2014). Source: Data provided by the Police Headquarters of Baranya, Somogy and Zala counties. http://www.hu-hr-ipa.com 


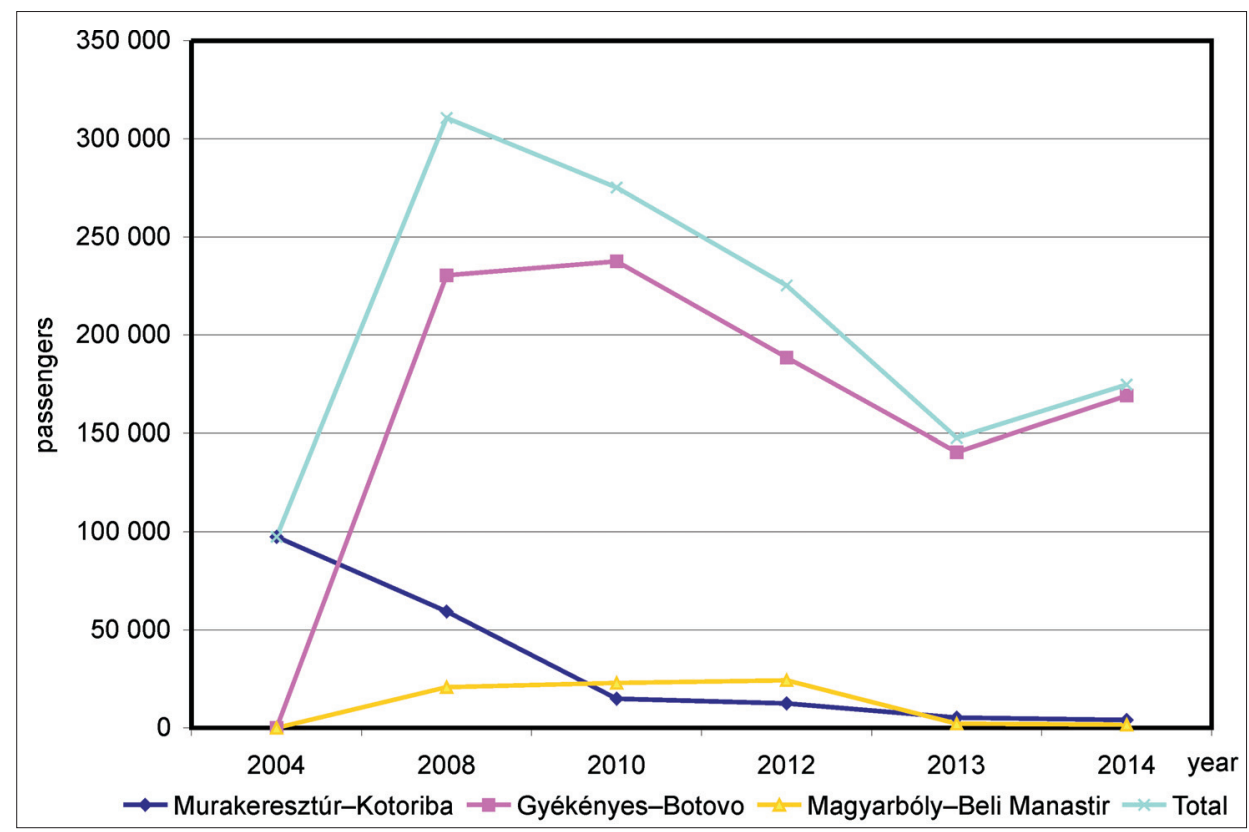

Fig. 4. Border railway traffic data of the Croatian-Hungarian border section (2004-2014). Source: Data provided by the Police Headquarters of Baranya, Somogy and Zala counties (Hungary), http://www.hu-hr-ipa.com

mainly food. Many small towns and settlements alongside the border (Barcs, Letenye, Berzence, Mohács) as well as bigger cities (Nagykanizsa, Pécs), were overwhelmed by Croatian shopping tourists in those years. Croatian language knowledge seemed to be a great labour market advantage and shopping tourism in the region highly relied on Croatian speaking shop assistants. After 2000 with the opening of the first big shopping malls in Croatia, the interest for shopping in Hungary decreased. In parallel, inflation and EU accession raised prices in Hungary so there seemed to be no reason any more for frequent travelling (OpAčıć, V.T. et al. 2004).

Water transport on Drava and Mura rivers exists only at a symbolic level ${ }^{23}$. As of its transit character (Pan-European transport corridor VII) the only cross-border river way used is the Danube (ports Mohács in Hungary

\footnotetext{
${ }^{23}$ Source: Data provided by the Police Headquarters of Baranya, Somogy and Zala counties (Hungary). http://www.hu-hr-ipa.com/en/documents-draft-op
}

and Vukovar in Croatia). Railway network is underdeveloped, especially in Croatia, with plans for reconstruction financed via EU Funds. There is only one important train station, in Koprivnica, in the whole border area with Hungary. A significant problem is that the rail network does not enable commuting to the main employment centres for most of the people due to long travel time and high costs (TÉsits, R. et al. 2013). Figure 4 presents border crossing data for three existing Croatian-Hungarian railway border crossing points in the period of 2004-2014, characterised with a considerable decrease in the number of passengers. The most remarkable is Murakeresztúr-Kotoriba (Western part of border zone) where the number of passengers was 97,299 in 2004, and this figure dropped to 3,978 by 2014 . The last international train interconnecting Zagreb and Budapest via that border-crossing was terminated in December 2008 , since then only local cross-border trains operate once a day. 
Out of three railway border crossings the most important is Gyékényes-Botovo (Koprivnica), but also with decreasing significance: 230,475 passengers (2004) dropped to 140,403 (2013) (Figure 4). Suspending InterCity (IC) train Budapest-Venice at the end of 2011 and Budapest-Zagreb-Rijeka, furthermore Budapest-Pécs-Osijek-Sarajevo at the end of 2012 led to only one daily train line operating since the $10^{\text {th }}$ of December 2012 between Hungary and Croatia. In December 2013 one IC train from Budapest to Zagreb was put back to operation (now via Kaposvár) improving the situation and resulting in a modest increase of passengers by 2014 at GyékényesBotovo. At Magyarbóly-Beli Manastir crossing, after abolishing the international train to Sarajevo, the number of passengers dropped from 24,240 (2012) to 1,663 (2014). It is quite clear that the elimination of the abovementioned train connections negatively influenced the overall cross-border traffic.

The refugee/migrant crisis occurring on the Croatian-Hungarian border section from the middle of September 2015 had further negative impacts. The suspension of the international railway transport, which is still lasting until further notice on the given section, left as the only possibility to travel with car or bus between two countries. Currently, it is still not possible to travel by train between Hungary and Croatia (http://www.mavcsoport.hu).

Regular public transport through the border area does not exist at all. Besides the mentioned limited and currently suspended train lines between Budapest and Zagreb, a bus line has been connecting the two capitals twice a week since July 2013, with an increasing frequency since then. A weekend bus line operates in the Pécs-Osijek-Pécs destination, but this limited possibility does not allow mobility for students or teachers between the two cities. Bus transport could serve more settlements than the train, but the long travel time (from Pécs to Osijek three hours) does not currently support its usage in the border area. Higher fuel prices in both countries have been hindering commuting by car for most of the inhabitants of the border zone.

\section{Mobility in the Croatian-Hungarian border area}

The border zone shows a typically low mobility character. The mobility of the labour force in the cross-border area is negatively influenced by the strong language barrier. Next to language and transport barriers further reasons for the low mobility can be specified: lack of information and transparency, level of wages, taxes and differences in the social security system, legal and administrative problems, lack of recognition of qualifications and cultural differences. Based on the analysis of the Mobile region project in 2011, there are several conclusions:

- Mobility between Hungary and Croatia is very low,

- The lack of mobility in Croatia is even considered as a threat,

- Hungary has the lowest percentage of citizens in the EU willing to move for a job change,

- Policies encouraging mobility and reducing its risks do not exist.

The accession of Croatia to the EU has not brought significant changes in labour mobility and there are only some sporadic examples. Accessibility of the closest border-crossing by road is poor which also negatively influences mobility in the Croatian-Hungarian border area. It is especially visible between crossing points Terezino Polje-Barcs and Donji Miholjac-Drávaszabolcs, where a border-crossing does not exist at the distance of 95 kilometres (see Figure 2).

\section{Croatian-Hungarian cross-border co- operation}

Compared to the Hungary-Croatia Pilot Small Projects Fund in 2002-2003, which was the beginning of cross-border co-operation, but with funding possibility only on the Hungarian side, furthermore to the Neighbourhood Programme Slovenia-Hungary-Croatia 2004-2006, the Hungary-Croatia (IPA) Cross-border Co-operation Programme 
2007-2013 has been a huge step forward in joint co-operation. In the period 2007-2013, IPA brought significant changes, by introducing single set of rules and the Lead Beneficiary principle. Those modifications have also affected the Hungarian-Croatian crossborder co-operation by forming bilateral programme in 2007-2013 period, with 169 jointly implemented projects and small or medium-scale developments (CsAPó, J. et al. 2015). The bilateral cross-border co-operation is continuing in the 2014-2020 EU Interreg $\mathrm{V}$-A period as well.

In the period between 2007 and 2013 the prime focus of the HU-HR (IPA) CBC Programme was on environmental/nature protection and tourism development (Č ELAN, T.J. 2015). A Hungarian-Croatian Regional Tourism Product Plan (RTPP) was elaborated (VARJú, V. et al. 2013) as a joint tourism strategy and set the basis for all other tourism related projects ${ }^{24}$. Finally, 40 percent of the available funds (54.8 million EUR) for in Hungary especially in the bordering regions since the change of regime and especially after the EU accession (Aubert, A. et al. 2012; CsAPó, J. 2014). However, a politically driven tourism development in a cross-border context can be problematic, especially regarding economic and social sustainability (Prokkola, E.K. 2008; Aubert, A. et al. 2008). It might be concluded that in the CroatianHungarian border zone without the EU funded Programme co-operation might not exist on a large scale, so the present development is artificial to a certain extent. The development in the border area is neither balanced (Table 1), nor naturally driven except for some small areas of traditional co-operations like on both sides of Baranya/Baranja and the Mura River (CsAró, J. et al. 2015). In both areas, Pannon EGTC and Mura Region EGTC ${ }^{26}$ have been established as the first attempts of creating more functional cross-border region, but it has not reached the complex development level of the transborder region.

Table 1. HU-HR (IPA) CBC Programme 2007-2013 county absorption of available EU funds and values per inhabitant

\begin{tabular}{l|c|c|c}
\hline \multicolumn{1}{c|}{ NUTS III level/Counties } & EU contribution in EUR & Population in 2011 census & EUR/person \\
\hline Somogy megye & $4,164,741$ & 316,137 & 13 \\
Zala megye & $6,877,942$ & 282,179 & 24 \\
Koprivničko-križevačka županija & $3,843,085$ & 115,584 & 33 \\
Virovitičko-podravska županija & $3,165,675$ & 84,836 & 37 \\
Baranya megye & $15,656,832$ & 386,441 & 41 \\
Osječko-baranjska županija & $13,317,197$ & 305,032 & 44 \\
Međimurska županija & $5,266,338$ & 113,804 & 46 \\
\hline
\end{tabular}

Source: http://www.hu-hr-ipa.com, http://www.ksh.hu, http://www.dzs.hr/default_e.htm.

CsApó, J. et al. 2015, http://www.terinno.hu/szamok/teruletfejlesztes_es_innovacio_2015_2.pdf

the Programme were allocated to tourism projects ${ }^{25}$. The amount proved to be higher than expected during the planning process, showing that tourism might be the strongest direction of development in the border area.

Cross-border co-operation and tourism development have always been on the agenda

${ }^{24}$ Including the su mmarised publicly available (2011) compendium called Handbook to Tourism Projects in the Hungary-Croatia IPA Cross-border Co-operation Programme.

${ }^{25}$ http://www.hu-hr-ipa.com/en/open-calls-forproposals/third-call-for-proposals-november-2011/16

\section{Conclusions}

The aim of this paper was to analyse the current socio-economic changes in the CroatianHungarian border zone, and to understand how these changes have affected the development of the region. It can be concluded that the development of the area is neither naturally driven, nor balanced. There are

\footnotetext{
${ }^{26}$ http://www.huhr-cbc.com/en/official-documents; http://www.pannonegtc.eu/; http://muraregio.eu/en/
} 
several obstacles that hinder proper crossborder relations:

a) The spatial structure shows imbalance, and demographic trends becoming more and more negative in the last intercensal periods further disable the possibility for co-operation in the area. Population decrease from 1991 and until the last census in 2011 officially amounts to 185,594 persons.

b) The Croatian-Hungarian language barrier is particularly strong and joint communication is almost impossible without English or German.

c) Road transport conditions have improved, with construction of new motorways, but until now it has not achieved any significant positive effect on the border area, which is still in a peripheral position. Although low and stagnating, road border crossings still showed relative stability in the last decade. The latest data received for 2014 showed sudden significant increase on all road bordercrossings between Croatia and Hungary.

d) Cross-border rail traffic has almost disappeared. The refugee/migrant crisis occurring on the Croatian-Hungarian border section since the middle of September 2015 has had additional negative effect on the transport across the border area (e.g. suspension of the international train transport).

e) Mobility is especially low in the border area, and with minor exceptions, daily labour commuting does not exist.

According to our conclusions there are some positive changes to be noticed in the area. Regional planning has become more coordinated in the period 2007-2013, as the bilateral Hungary-Croatia (IPA) CBC Programme was for the first time programmed and implemented with joint participation of both countries. The planning of the new Interreg V-A Hungary-Croatia Co-operation Programme 2014-2020 is also elaborated jointly. The outputs and results of the present Programme, with significant increase of joint projects and small or medium developments around the Mura-Drava-Danube area, with the highest interest for joint tourism projects, is a large step forward for the border zone and the local communities. However, such partly politically driven tourism development in a cross-border context can be problematic, as it might lead to the conclusion that it is at a certain extent an artificial development. Otherwise, as outlined in this paper, without the EU funded cross-border co-operation programme strong interaction would not exist in the Croatian-Hungarian border area. Those tangible small positive changes are anyhow not sufficient enough to minimise the barriers and the strong periphery status of the border area, especially when compared to Zagreb and Budapest.

Due to development problems in the peripheral areas, the transborder region has not been formed yet along the Croatian-Hungarian border (Opačić, V.T. et al. 2004). That recapitulation was formulated 12 years ago and it is still valid, taking into account the current negative demographic trends, the language barrier, the peripheral location, the low mobility of people and limited cross-border traffic. As a final conclusion, it can be confirmed that the transborder region has still not been formed alongside the Croatian-Hungarian border, but the crossborder activity is more significant than in the previous decade. It brought stronger co-operation in the area and two European Groupings of Territorial Cooperation (EGTCs) have been recently formed as well.

\section{REFERENCES}

Aubert, A. and Csapó, J. 2008. Tourism cooperation opportunities in the Danube-Drava-Sava Euroregion. In Neighbours and partners: on the two sides of the border. Ed.: SüLI-ZAKAR, I. Debrecen, Kossuth Egyetemi Kiadó, 299-309.

Aubert, A., Csapó, J., Marton, G. and Szabó, G. 2012. The development of cross-border cooperation in the strategy of the Datourway programme, $10^{\text {th }}$ International Conference of Geography. Geographica Timisiensis 21. (2): 115-125.

Bufon, M. 1993. Elementi obmejnosti in faktorji oblikovanja prekomejnih območij na primeru Slovenije, Dela 10. 99-109.

ČELAN, T.J. 2011. Mogućnosti regionalnog razvoja Hrvatske na primjeru IPA prekograničnog programa Mađarska-Hrvatska 2007-2013. Geografski horizont 57. (2): 21-40. 
ČElan, T.J. 2013. Dodatak/Rezultati 3. poziva IPA prekograničnog programa Mađarska-Hrvatska 2007-2013. Geografski horizont 59. (2): 40-46.

Čelan, T.J. 2014. A Historical Geographical Analysis of the Development of the Croatian-Hungarian Border. Modern Geográfia 4. 75-92.

ČElan, T.J. 2015. A Tourism Plan within a Crossborder Development Strategy: Sustainability of the Regional Tourism Product Plan of the Hungary-Croatia (IPA) Cross-border Co-operation Programme 2007-2013. Turizam 19. (2): 85-98.

CIA - The World Factbook. https://www.cia.gov/library/ publications/the-world-factbook/

Crkvenčić, J. and Crkvenčić, M. 2003. PrekodravljeRepaš Area Growth of Settlements and Population. Podravina: časopis za multidisciplinarna istraživanja 2. (4): 133-149.

Croatian Bureau of Statistics (English website): http:// www.dzs.hr/default_e.htm

Csapó, J. 2014. An Analysis of Tourism Oriented Cross Border Co-operations (2007-2013) between Hungary and Croatia. Czech Hospitality and Tourism Papers 10. (23): 48-63.

Csapó, J., Čelan, T.J. and TrócsáNYI, A. 2015. A határmenti együttműködés hatásai a területi fejlődésre a magyar-horvát szakasz példáján az EU tervezési mechanizmusának tükrében (2007-2013). (The effects of cross-border co-operation on regional development on the example of the Croatian-Hungarian border zone int he light of EU programming). Területfejlesztés és Innováció 2. 22-31.

Dávid, L., Tóth, G., Bujdosó, Z. and RemenYıк, B. 2011. The role of tourism in the development of border regions in Hungary. Romanian Journal of Economics 2. 109-124.

Državna geodetska uprava, Zagreb: http://www.dgu.hr/, official answer of 25.2.2014 (Class: 015-02/14-01/03, Number: 541-02-3/1-14-2).

EUROSTAT website: http://epp.eurostat.ec.europa. eu/portal/page/portal/eurostat/home/

Gulyás, L. and BALI, L. 2013. From the coexistence of border zones to integration: Characteristics of Croatian-Hungarian border relations from 1945 until today. Eurolimes, Autumn, 16. 13-26.

Hajdú, Z. 2004. Renewal of cross-border cooperation along the Hungarian-Croatian border. In Challenged borderlands: transcending political and cultural boundaries. Eds.: Pavlakovich-Kochi, V., Morehouse, B.J. and Wastl-Walter, D. Ashgate, Aldershot, Burlington, 109-122.

HajDú, Z. 2006. A magyar-horvát határ történeti, közjogi, közigazgatási kérdései 1918-ig. (Historical, juridical and administrative problems of the Hungarian-Croatian state border until 1918). Balkán Füzetek 4. 18-33.

Hardi, T. 2010. Cities, Regions and Transborder Mobility Along and Across the Border. Centre for Regional Studies of Hungarian Academy of Sciences. Discussion Papers 82. 27 p.
HavlíčEK, T. 2007. Border, borderland and peripheral regions. Theoretical considerations in the framework of the process of transformation. Issues in Geographical Marginality. Papers presented during the Commission Meetings 2001-2004, IGU, Grahamstown, South Africa, Rhodes University, 2-10.

HeкA, L. 2007. Hrvatsko-ugarska nagodba u zrcalu tiska. Zbornik Pravnog fakulteta Sveučilišta u Rijeci 28. (2): 931-971.

Hrvatska udruga koncesionara za autoceste s naplatom cestarine (HUKA). http://www.huka.hr/mrezaautocesta

Hungary-Croatia Cross-border Co-operation Programme (http://www.hu-hr-ipa.com) with the programming document (2007-2013). (http://www.hu-hr-ipa.com/ en/downloads /programming-document)

KLemenčić, M. 1991. Historijsko-geografska osnovica hrvatsko-mađarske granice (The historical-geographical background of Croatian-Hungarian border). Politička misao 28. (1): 182-191.

KÖZOP-3.5.0-09-11-2012-0003 project with the respective decision of the Hungarian Government: http://www.kozlonyok.hu/nkonline/MKPDF/ hiteles/MK16007.pdf

Központi Statisztikai Hivatal / Hungarian Central Statistical Office. http://www.ksh.hu

LANG, T. 2015. Socio-economic and Political Responses to Regional Polarisation and socio-spatial peripheralisation in Central and Eastern Europe: a research agenda. Hungarian Geographical Bulletin, 64. (3): $171-185$.

Magyar Közút Nonprofit Zrt. http://www.motorway.hu/

Martinez, O.J. 1994. The dynamics of border interaction: New approaches to border analysis. In Global Boundaries. World Boundaries Series 1. Ed.: SCHOFIELD, C.H. London-New York, Routledge, 1-15.

Máté, É., Makkai, B., Pirisi, G. and Trócsányi, A. 2016. Shrinking small towns - inadequate strategies? Experiences from rural Hungary. (under publishing process)

Opačić, V.T. and Crlenko, I. 2004. Demographic trends and border traffic as indicators of (non-)existing transborder region in Croatian-Hungarian border area. Geoadria 9. (1): 73-88.

Pepeonik, Z. 1985. Traveller crossings along Yugoslav boundary with special consideration for passes between Yugoslavia and Hungary. Geographical papers $6.157-161$.

Perkmann, M. 2003. Cross-Border Regions in Europe: Significance and Drivers of Regional Cross-Border Co-operation. European Urban and Regional Studies 10. (2): 153-171.

Pirisi, G. and Trócsányi, A. 2012. The development of the Hungarian settlement network since 1990. In Development of the Settlement Network in the Central European Countries: Past, Present, and Future. Eds.: Csapó, T. and Balogh, A. Berlin-Heidelberg, Springer Verlag, 63-75. 
Planning documents of the Interreg V-A HungaryCroatia Co-operation Programme 2014-2020, http:// www.huhr-cbc.com/en/official-documents

Police Headquarters of Baranya, Somogy and Zala counties (Hungary): Border crossing data on the border crosses of Hungary and the Republic of Croatia, 2004-2013.

РвоккоLA, E.K. 2008. Resources and barriers in tourism development: cross-border cooperation, regionalization and destination building at the Finnish-Swedish border. Fennia 186. (1): 31-46.

Statistical Yearbook of the Republic of Croatia, 2013. 588 p., http://www.dzs.hr

Stokєosa, K. and Besier, G. 2014. European Border Regions in Comparison: Overcoming Nationalistic Aspects or Re-Nationalization? Routledge Studies in Modern European History. Book 21. New York-London, Routledge, 379 p.
Tésits, R. and Alpek, L. 2013. Some aspects of the labour force mobility of the Drava Region. Modern Geográfia 1. 1-12.

van Houtum, H. 2000. An overview of European geographical research on borders and border regions. Journal of Borderland Studies 15. (1): 57-83.

Varjú, V., Suvák, A. and Dombi, P. 2013. Geographic Information Systems in the Service of Alternative Tourism - Methods with Landscape Evaluation and Target Group Preference Weighting. International Journal of Tourism Research. Doi: 10.1002/jtr.1943. http:// onlinelibrary.wiley.com/doi/10.1002/jtr.1943/full 